The University of Maine

\title{
DigitalCommons@UMaine
}

Marine Sciences Faculty Scholarship

School of Marine Sciences

$1-1-1975$

\section{Nighttime Catches of Fishes in a Tidal Cove in Montsweag Bay Near Wiscasset Maine}

James McCleave

University of Maine - Main, mccleave@maine.edu

S.M. Fried

Follow this and additional works at: https://digitalcommons.library.umaine.edu/sms_facpub

\section{Repository Citation}

McCleave, James and Fried, S. M., "Nighttime Catches of Fishes in a Tidal Cove in Montsweag Bay Near Wiscasset Maine" (1975). Marine Sciences Faculty Scholarship. 78.

https://digitalcommons.library.umaine.edu/sms_facpub/78 


\title{
Nighttime Catches of Fishes in a Tidal Cove in Montsweag Bay near Wiscasset, Maine
}

\author{
James D. McCleave and Stephen M. Fried \\ Department of Zoology \\ University of Maine \\ Orono, Maine 04473
}

\begin{abstract}
Summer nighttime abundance and localized distribution of fishes in a tidal cove were studied by beach seining for comparison with a previous daytime study. American eels were relatively abundant at night and absent during the day. Alewife, blueback herring, and Atlantic silverside were more abundant in the cove at night. Although mummichog numbers were greatly reduced at night, they remained an important constituent of the night fauna. Lesser components of the night fauna included Atlantic herring, Atlantic tomcod, smooth flounder, winter flounder, and rainbow smelt.
\end{abstract}

The objectives of this study were to assess the summer nighttime abundance and localized distribution of fishes in a small (9.9 hectare) estuarine cove and to compare the results with those of a previous daytime study of the cove (Targett and McCleave 1974). The daytime fauna of the cove was dominated by an inshore species, the mummichog (Fundulus heteroclitus).

Recksiek and McCleave (1973) and Koch (1974) found that four species comprised over $95 \%$ of the summer pelagic fish catches in the more open water areas of Montsweag Bay: alewife (Alosa pseudoharengus), blueback herring ( $A$. aestivalis), Atlantic menhaden (Brevoortia tryannus), and Atlantic herring (Clupea harengus). Similarly, Fried (1973) found that four species comprised over 95\% of the summer demersal fish catches in the main channel of Montsweag Bay: Atlantic tomcod (Microgadus tomcod), winter flounder (Pseudopleuronectes americanus), smooth flounder (Liopsetta putnami), and white hake (Urophycis tenuis). Yet, of these eight species, only smooth flounders and Atlantic herring were important components of the daytime cove fauna (Targett and McCleave 1974). We wondered if these species might utilize the cove to a greater extent at night, and generally how the composition of the cove fauna would differ at night.

\section{MATERIALS AND METHODS}

Fishes were captured with a beach seine $30.5 \mathrm{~m}$ by $1.2 \mathrm{~m}$ of $6-\mathrm{mm}$ square mesh, with a $1.2-\mathrm{m}$ by $1.2-\mathrm{m}$ by $1.2-\mathrm{m}$ bag. Collections were made at the same two stations used by Targett and McCleave (1974) : a low tide station near the outer end of the long, narrow cove and a high tide station near the inner end. At each station, when the water depth was approximately $40 \mathrm{~cm}$, the seine was hauled parallel to the long axis of the cove for a distance of $40 \mathrm{~m}$ before being pursed. All fishes in the seine bag were taken back to the laboratory, frozen and later thawed, and counted and weighed by species. Alewives and blueback herring were treated as one "species" because of the difficulty of distinguishing juveniles, especially after freezing and thawing. Immediately prior to each seine haul water temperature was recorded and a water sample taken for salinity determination. During the entire sampling period temperature ranged from $18.0-22.6 \mathrm{C}$ and salinity from $10.2-22.4 \%$.

Night collections were made 3 and 7 July and 16 and 22 August 1973. Four seine hauls were made each month, one on the flood and one on the ebb tide at each of the two stations. To avoid daylight, flood and ebb tides had to be fished several nights apart. A daylight collection of four seine hauls during a complete tidal cycle was made 16 July 1973 to detect any gross changes since the Targett and Mccleave (1974) study.

\section{RESULTS}

A total of 5,029 fishes representing 10 species was captured in eight night seine 
TABLE 1.-Numbers of fishes seined in the summer of 1973 in a Maine tidal cove in eight night and four day hauls, compared with day seine catches of Targett and McCleave (1974) during the summers of 1971 and 1972. (Percentages of total numbers in parentheses)

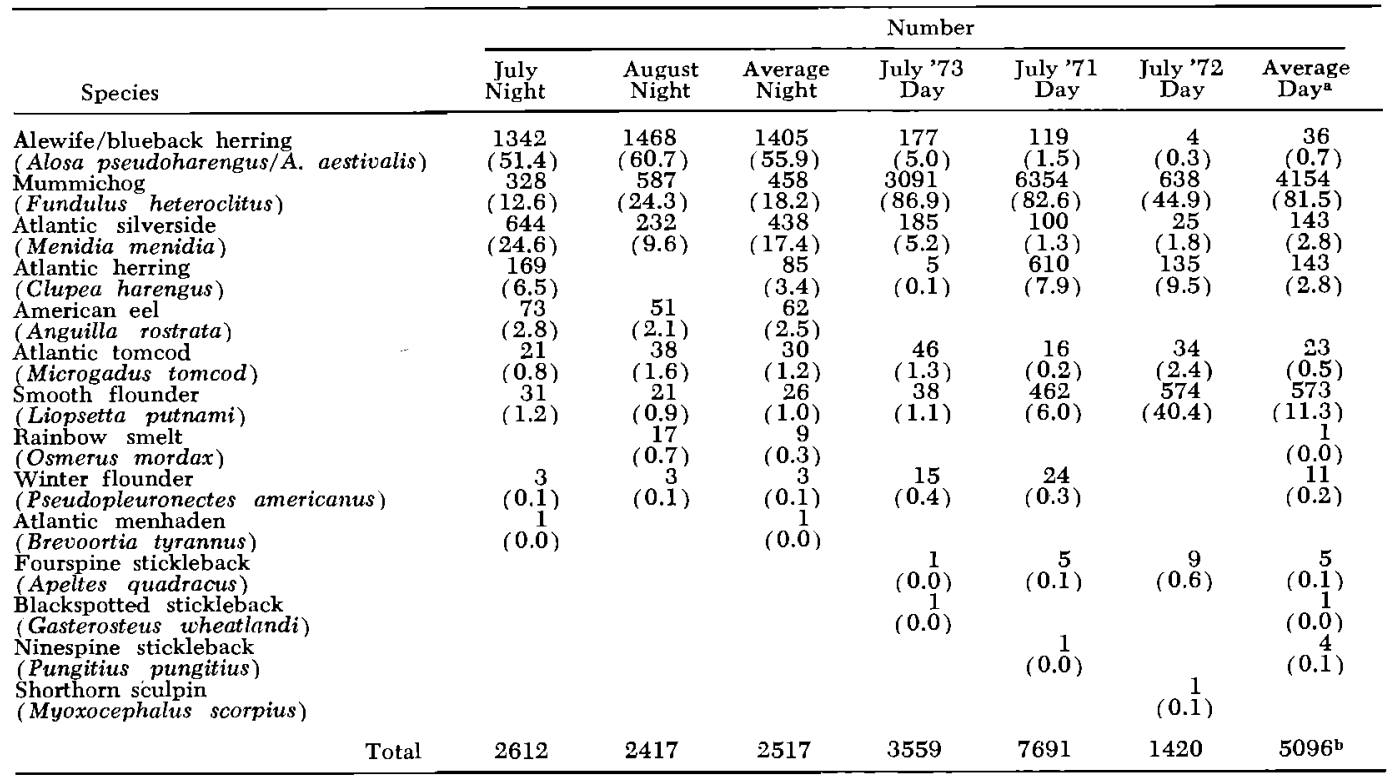

a Daily mean of seven dates of Targett and McCleave (1974).

b Other species were caught less frequently than one per seine haul.

hauls, while 3,559 fishes representing 9 species were captured in four day seine hauls (Table 1). Five species comprised $97.4 \%$ of the total night catch: alewife/blueback herring, mummichog, Atlantic silverside, Atlantic herring and American eel. Three species comprised 97.1\% of the total day catch: mummichog, Atlantic silverside and alewife/blueback herring. Four of the five most abundant night species also contributed $94.2 \%$ of the total catch weight, but in slightly different order (alewife/blueback herring, 78.4\%; American eel, $11.8 \%$; Atlantic silverside, 4.6\%; mummichog, 3.0\%). During the day, percentage catch-by-weight was similar to percentage catch-by-numbers for all species.

All sizes (ages) of American eels and the strictly inshore species, mumichogs, Atlantic silversides, and sticklebacks, were captured in the cove, but virtually the entire catch of all other species was young-of-the-year and juvenile fish.

All 12 seine hauls caught alewife/blueback herring, Atlantic silverside and, although never numerous, smooth flounder. Atlantic herring were caught only in July, and rainbow smelt only in August.

Four species exhibited especially large diel fluctuations of abundance in the cove. American eels of all sizes were moderately abundant at night in terms of both numbers $(2.5 \%$ of total catch) and biomass $(11.8 \%$ of total catch), but were never captured in the daytime by us or by Targett and McCleave (1974). Alewife/blueback herring and Atlantic silverside were considerably more numerous in the cove at night, whereas mummichog numbers were greatly reduced at night.

Differences occurred in the localized distribution of some fishes within the cove (Table 2). Mummichogs were caught in greater numbers (chi-square, $p<0.01$ ) at the inner end of the cove (station $\mathrm{H}$ ), and Atlantic tomcod were caught in greater numbers $(p<0.01)$ at the outer end (Station L), on all night and day sampling dates. Rainbow smelt and winter flounder were caught only at the outer station. Alewife/blueback herring and Atlantic silverside exhibited inconsistent, though significant, differences, presumably because of 
TABLE 2.-Chi-square comparisons of fish catches in eight night seine hauls and four day seine hauls at $a$ high and a low tide station in flood and ebb tides. (Significantly greater catches $(p<0.01$ ) are indicated by: $E=e b b$ tide, $F=$ flood tide, $H=$ high tide station, $L=$ low tide station, $n=$ nonsignificant comparisons, blank = sample size equal to zero)

\begin{tabular}{|c|c|c|c|c|c|c|}
\hline \multirow[b]{2}{*}{ Species } & \multicolumn{3}{|c|}{ Station } & \multicolumn{3}{|c|}{ Tide stage } \\
\hline & $\underset{\text { Nuly }}{\text { Night }}$ & $\begin{array}{l}\text { August } \\
\text { Night }\end{array}$ & $\underset{\text { Duly }}{\text { Day }}$ & $\begin{array}{l}\text { July } \\
\text { Night }\end{array}$ & $\begin{array}{l}\text { August } \\
\text { Night }\end{array}$ & $\begin{array}{l}\text { July } \\
\text { Day }\end{array}$ \\
\hline Alewife/blueback herring & $\mathbf{n}$ & $\mathrm{L}$ & $\mathrm{H}$ & $\mathbf{E}$ & $\mathbf{E}$ & $\mathbf{E}$ \\
\hline Atlantic silverside & $\mathbf{H}$ & $\mathrm{L}$ & $\mathrm{H}$ & $\mathbf{E}$ & $\vec{E}$ & $\mathbf{n}$ \\
\hline Mummichog & $\mathbf{H}$ & $\mathbf{H}$ & $\mathrm{H}$ & $\mathbf{E}$ & $\overline{\mathbf{E}}$ & $\mathbf{E}$ \\
\hline American eel & $\mathrm{H}$ & $\mathrm{n}$ & & $\mathbf{E}$ & $\mathbf{n}$ & \\
\hline Atlantic tomcod & $\mathrm{L}$ & L & $\mathbf{L}$ & $\mathrm{n}$ & $\mathbf{E}$ & $\mathrm{E}$ \\
\hline Smooth flounder & $\mathrm{n}$ & $\mathbf{n}$ & n & $\mathrm{n}$ & $\mathbf{n}$ & $\mathbf{n}$ \\
\hline Winter flounder & $\mathrm{n}$ & $\mathbf{n}$ & L & $\mathrm{n}$ & $\mathbf{n}$ & $\mathbf{n}$ \\
\hline $\begin{array}{l}\text { Atlantic herring } \\
\text { Rainbow smelt }\end{array}$ & $\mathrm{H}$ & $\mathbf{L}$ & $\mathbf{n}$ & $\mathbf{E}$ & $\mathbf{E}$ & $\mathbf{n}$ \\
\hline
\end{tabular}

the patchy distribution of such schooling species.

Some species also exhibited differences of abundance with the two tidal stages (Table 2). Alewife/blueback herring and mummichogs were always caught in greater numbers on the ebb tide $(p<0.01)$. All other species exhibiting significant abundance differences during at least one sampling period were also most numerous on the ebb tide.

None of the diel, locale, or tidal differences in catches was attributable to temperature or salinity differences.

\section{DISCUSSION}

Surprisingly little is known concerning differences in the day-night usage of various habitats by fishes, though some studies of tropical marine fishes (e.g., Hobson 1965, 1968) and freshwater fishes (e.g., Emery 1973) have been published. Roessler (1965) and Hoese et al. (1968) found night trawl catches to contain more individuals and more species than day trawl catches over the same grounds. This pattern did not appear in our beach seine study. Lower numbers of fishes and equal numbers of species, although not necessarily the same species, were caught during the night as compared to the day. Daytime gear avoidance may play a more important role in open water trawling than in restricted shallow water seining. Gear avoidance did affect our results, however, since we know from gillnetting that Atlantic menhaden, striped bass (Morone saxatilis), and shortnose sturgeon (Acipenser brevirostrum) are found at least at the mouth of the cove at night. These larger fishes are not vulner- able to seining. Additionally we were not able to assess abundance in the cove during stages of tide when water level was high. More fish may have been present then, especially at night.

The summer nighttime fish fauna of the cove and the summer pelagic fauna of the more open waters are both comprised chiefly of alewives and blueback herring [55.9\% of the total night catch in the cove, $87.7 \%$ in the channel of Montsweag Bay (Recksiek and McCleave 1973) ]. However, the demersal fauna of the channel, dominated by Atlantic tom$\operatorname{cod}(38.2 \%$ of the total summer catch), winter flounder $(21.2 \%)$, smooth flounder $(20.6 \%)$, and white hake $(16.7 \%)$ (Fried, 1973 ), was only poorly represented in the cove during both day and night (Table 1). Since Targett and McCleave (1974) did find that smooth flounders represented $11.3 \%$ of the daytime catch in the cove, it is possible that the low number $(1.0 \%)$ captured during the present study was due to relatively unsuccessful spawning during the winter of 1973. Fried (1973 and unpublished data) determined that the average size of smooth flounder captured by trawl in the channel of Montsweag Bay was greater in 1973 than in 1972 and 1971, due to a smaller percentage of young flounder.

Some differences between day and night catches in the cove appear to result from previously reported diel behavioral patterns. American eels are known to be nocturnal (Smith and Saunders 1955). Both the migratory activity of adult anadromous alewives (Saila et al. 1972) and the feeding activity of landlocked alewives (Emery 1973) are reported to be distinctly diurnal. Therefore, 
our larger night catches of alewife/blueback herring may have resulted from movement into shallow water unrelated to feeding, a phenomenon Emery (1973) has previously reported. Mummichogs are present in large numbers during the day, but drop considerably in numbers at night. Since mummichogs are considered to be strictly inshore fish (Bigelow and Schroeder 1953), they may burrow into the mud and be less vulnerable to the seine at night. This behavior has been observed when they are trapped by a falling tide (Mast 1915).

Winter flounder are primarily sight feeders (Pearcy 1962), feeding during the day and becoming quiescent at night (Olla, Wichlund, and Wilk 1969). We captured a few more during the day than at night, but this study and that of Fried (1973) suggest that small winter flounder are not abundant in the channels or coves of Montsweag Bay. The species probably does not spawn in the bay.

Stickney (1972) reported that Atlantic herring were diurnally active with higher crepuscular peaks of activity, and Blaxter (1964) found that feeding ceased at low light intensities. We caught them primarily at night, but Targett and McCleave (1974) caught them often in daylight. Such spotty catches are probably a result of the herring's aggregation behavior.

Hobson $(1965,1968)$, in scuba and snorkeling studies of Gulf of California inshore fishes, reported that the nocturnal species were carnivores, while diurnal species included herbivores, omnivores, and carnivores. Emery (1973) divided Ontario lake fishes into plankton feeders, larger predators, and benthic invertebrate feeders. The larger predators were crepuscular, but there were plankton feeding species and benthic carnivorous species active at all times. Our findings agree. Species presumably feeding in the cove at night (Atlantic silverside and American eel) are carnivores, and the major omnivore (mummichog) is diurnal. Benthic carnivores (smooth flounder, winter flounder, and Atlantic tomood) are found in the cove both day and night, though always in limited numbers. Planktivores (alewife, blueback herring, and Atlan- tic herring) are in the cove day and night, but alewife and blueback herring may not feed there at night.

\section{ACKNOWLEDGMENTS}

We thank Messrs. Andrew Towt, Peter Koch, and Timothy Targett for assistance in the field. Funds were provided by Maine Yankee Atomic Power Company.

\section{LITERATURE CITED}

Bigelow, H. B., aNd W. C. Schroeder. 1953. Fishes of the Gulf of Maine. U.S. Fish Wildl. Serv., Fish. Bull. 74: 1-577.

Blaxter, J. H. S. 1964. Spectral sensitivity of the herring, Clupea harengus L. J. Exp. Biol. 41: $155-162$.

EMERY, A. R. 1973. Preliminary comparisons of day and night habits of freshwater fish in Ontario lakes. J. Fish. Res. Board Can. 30: 761-774.

Fried, S. M. 1973. Distribution of demersal fishes in Montsweag Bay-Back River and lower Sheepscot River estuaries, Wiscasset, Maine. M.S. Thesis, Univ, of Maine, $48 \mathrm{p}$.

Hosson, E. S. 1965. Diurnal-nocturnal activity of some inshore fishes in the Gulf of California. Copeia 1965: 291-302.

—_ 1968. Predatory behavior of some shore fishes in the Gulf of California. U.S. Fish Wildl. Serv., Res. Rep. 73: 1-92.

Hoese, H. D., B. J. Copeland, F. N. Moseley, and E. D. Lane. 1968. Fauna of the Aransas Pass Inlet, Texas. III. Diel and seasonal variation in trawlable organisms of the adjacent area. Texas J. Sci, 20: 33-60.

Kосн, P. 1974. Distribution of pelagic fishes in a Maine estuary subject to thermal pollution. M.S. Thesis, Univ. of Maine. $51 \mathrm{p}$.

MasT, S. O. 1915. The behavior of Fundulus with especial reference to overland escape from tidepools and locomotion on land. J. Anim. Behav. 5: $341-350$.

Olla, B. L., R. Wicklund, AND S. Wilk. 1969. Behavior of winter flounder in a natural habitat. Trans. Amer. Fish. Soc. 98: 717-720.

Pearcy, W. G. 1962. Ecology of an estuarine population of winter flounder, Pseudopleuronectes americanus (Walbaum). IV. Food habits of larvae and juveniles. Bull. Bingham Oceanogr. Coll. 18: $65-78$.

RecksieK, C. W., and J. D. McCleave. 1973. Distribution of pelagic fishes in the Sheepscot River-Back River estuary, Wiscasset, Maine. Trans, Amer. Fish. Soc. 102: 541-551.

RoEssler, M. 1965. An analysis of the variability of fish populations taken by otter trawl in Biscayne Bay, Florida. Trans. Amer. Fish. Soc. 94: 311-318.

Salla, S. B., T. T. Polgar, D. H. Sheehy, and J. M. FLowers. 1972. Correlations between alewife activity and environmental variables at a fishway. Trans. Amer. Fish. Soc. 101: 583-594. 
Smith, M. W., and J. W. Saunders. 1955. The American eel in certain fresh waters of the maritime provinces of Canada. J. Fish. Res. Board Can. 12: 238-269.

STICKNEY, A. P. 1972. The locomotor activity of juvenile herring (Clupea harengus harengus L.) in response to changes in illumination. Ecology 53: $438-445$.

Target't, T. E., and J. D. McCleave. 1974. Summer abundance of fishes in a Maine tidal cove with special reference to temperature. Trans. Amer. Fish. Soc. 103: 325-330. 